\section{Use of numerical method for optimization of granulometric curves in eco-efficient concrete}

\author{
${ }^{1}$ Instituto Federal de Educação, Ciência e Tecnologia da Paraíba - IFPB, Departamento de Construção Civil, Rua José \\ Antônio da Silva, 300, 58900-000, Paraíba, Cajazeiras, Brasil. \\ ${ }^{2}$ Universidade Federal da Paraíba, Programa de Pós-Graduação em Engenharia Civil e Ambiental (PPGECAM) - Centro \\ de Tecnologia, Cidade Universitária, 58051-900, Paraíba, João Pessoa, Brasil. \\ ${ }^{3}$ Instituto Federal de Educação, Ciência e Tecnologia da Paraíba - IFPB, Departamento de Construção Civil, Avenida \\ Primeiro de Maio, 720, 58015-435, Paraíba, João Pessoa, Brasil. \\ e-mail: robson.santos@ifpb.edu.br, bezerrawesleyvitor@gmail.com, gibson@ifpb.edu.br, franciscoalisson@ hotmail.com, \\ dayvison_16@hotmail.com
}

\title{
ABSTRACT
}

Concrete is the most used construction material and thus, being the cement a significant part of this material, it is also widely used around the world. Cement production is responsible for more than $5 \%$ of global $\mathrm{CO}_{2}$ emissions, which has been continuously increasing. A solution to reduce the cement content in concretes without loss of performance is thorough the particle packing optimization. This work uses practical numerical simulations through linear programming and the modified Andreasen \& Andersen model to reduce the void content of aggregate mixtures and produce concretes with superior and intermediate packing levels. A broad range of distribution modulus "q" values were tested. Deviations between the particle size distribution (PSD) curves were calculated in each step of the process. In this study, mixtures with the smallest deviations - experimental PSD curves closer to the mathematical packing model - did not present the lowest void contents. The distribution modulus " $q$ " directly affects the fine aggregate content in the mixtures: lower q values favors higher fine aggregate contents. For concrete granular skeletons composed by sand and gravel, there is a $\mathrm{q}$ value below which sand is the top deviation contributor and above which gravel is the top deviation contributor. Moreover, there is a limit to the distribution modulus after which the void content of aggregate skeletons tends to increase. In this study, that was 0.30. Concretes with superior packing (S concrete) and with the lowest distribution factor $(q=0.25)$ showed better performance in relation to the other studied concretes, with a higher compressive strength at 91 days and with a binder intensity around 6 at 28 days and below 5 at 91 days.

Keywords: aggregate packing, eco-efficient concrete, granular skeleton; numerical simulations.

\section{INTRODUCTION}

Concrete is the most widely used construction material. As a consequence, being the cement a significant part of this material, it is also widely used around the world. Cement production is responsible for approximately $5-7 \%$ of the global $\mathrm{CO}_{2}$ emissions [1], which has been continuously increasing. The past 20 years alone are accountable for $66 \%$ of all cumulative cement-based $\mathrm{CO}_{2}$ emissions since 1928 [2]. Without technological innovations, the increasing demand for cementitious materials will increase the global $\mathrm{CO}_{2}$ emissions even more [3].

In this scenario, sustainable development is a justification and objective for many studies aimed at minimizing the environmental impacts from cement production. In the recent years, concepts such as sustainability and service life have started to be incorporated by the construction industry [4].

To produce more sustainable concretes, some possibilities are: the use of mineral additions as partial replacement of clinker in cement production; the reduction of the overall cement content used in concrete mixtures; the design of new materials (such as clinkers with higher reactivity and new binders); the replacement of natural aggregates by recycled ones, etc. [5]. However, to maintain or improve concrete performance 
while keeping it eco-friendly, those solutions must be adequately applied. For example, it has been reported that the use of some recycled aggregates can increase the cement consumption, which consequently impacts the $\mathrm{CO}_{2}$ emissions [6].

In several cases, the progress of eco-efficient concrete studies depends on the ability to develop solutions related to mixture design methods. In this context, packing theories to optimize concrete composition, and thus, reduce the void content have been included in some recent research studies [7, 8]. By doing that, lower quantities of cement are needed to reach the same mechanical performance. However, the use of particle packing models for concrete mixture purposes are still seldomly adopted [9].

This work uses particle packing principles to optimise the void content in concrete mixtures simultaneously to the incorporation of wastes from heavy ceramic industry. These procedures aimed to significantly reduce cement consumption in concrete mixtures, without loss of performance, and thus contribute to obtain a more eco-efficient material.

\subsection{Particle packing models}

Although particle packing can be verified, for example, by the unit mass measurement of the aggregate mixture, the particle packing models, many of them based on mathematical formulations, are more precise and controllable. These models aim to calculate the void content of a given set of particles with known dimensions [5].

The packing models can be classified in two basic approaches: a discrete one, which considers the particles individually $[10,11]$; and a continuous one, which examines the particle set as a continuous distribution [12].

The basis of discrete packing models is the particle packing of multiple monodispersions (particles of the exact same size) [12]. Since it is difficult to achieve monodispersions, most studies deal with narrow discrete size classes, which, even so, are continuously sized distributions and do not pack as expected from monodispersions [12].

Extending the discrete solution into a mixture with infinite discrete size classes, Furnas describes the packing efficiency as a continuous distribution, presented in equation (1) [10].

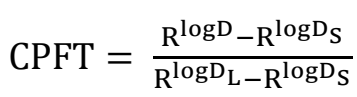

Where D is the particle size, CPFT (Cumulative Percent Finer Than) is the cumulative percentage of particles finer than D, DL is the largest particle size in the distribution, DS is the smallest particle size in the distribution, and $\mathrm{R}$ is the ratio between consecutive size classes, which are conveniently defined.

Another early attempt to optimize particle packing was the "Fuller-Kurve" by [13], presented in equation (2).

$$
\operatorname{CPFT}=\left(\frac{D}{D_{L}}\right)^{\mathrm{q}} \times 100
$$

Where D is the particle size, CPFT is the cumulative percent finer than D, DL is the largest particle size in the distribution, and $\mathrm{q}$ is a constant named distribution modulus.

With the same mathematical formulation of this Fuller equation, [14], based on experimental observations, suggested that q values should be in the range of 0.33 to 0.50 , this parameter being dependent of the particle characteristics.

After adding a missing proportionality factor to Furnas' equation and adding the smallest particle size variable to Andreasen's equation, [12] presented equation (3):

$$
\mathrm{CPFT}=\left[\left(\mathrm{D}^{\mathrm{q}}-\mathrm{D}_{\mathrm{S}}^{\mathrm{q}}\right) /\left(\mathrm{D}_{\mathrm{L}}^{\mathrm{q}}-\mathrm{D}_{\mathrm{S}}^{\mathrm{q}}\right)\right] \times 100
$$

Using numerical simulations, [12] showed that a q value of 0.37 optimizes their equation, which is often named as modified Andreasen \& Andersen grading model (modified A\&A) [7, 15]. Even so, this value of 0.37 still has its limitations because the particles used in the simulations were of spherical shape, which most concrete aggregates are not. 


\subsection{Aggregate packing optimization}

An optimized particle size distribution (PSD) curve with minimum voids can be obtained by either empirical tests (successive mixtures) or numerical solutions. Considering concrete research, this can be done for aggregates and binders or just for the aggregates. This study focuses on the later - optimization of aggregate skeletons.

The successive mixture method can be done in several ways. Manually, aggregates are mixed, and the unit mass of this mixture and the specific mass of each aggregate are used to calculate the overall void content. The mixture having the lowest void content is then chosen as optimum. An often-used process for this consists of mixing larger sized with intermediate sized particles, obtaining the best - lowest void content mixture of these two materials. This mixture is then combined with the next adjacent smaller particle class for new void content measurements. This continues until the smallest class of particles is used and a minimum void content is reached. This method is recommended by several authors that investigated conventional and self-compacting concretes [16]. On the other hand, with software aid, successive tries can be made by the generation of different grain size distribution curves (based on the characteristics of the available aggregates). Amongst those, the one which is closest to a given mathematical curve of a packing model (such as the Furnas and the modified A\&A) is selected.

However, if numerical solutions are used, a significant number of numerical curves can be automatically generated to ensure that the selected one presents the lowest distance possible from the mathematical curve, which can be obtained using the least-squares method. This method saves time and materials in comparison with successive mixtures.

Table 1 presents some studies available in literature that used the packing theory to design concrete mixtures, with their respective cement contents, packing model and distribution modulus values (if applicable). As shown, packing models are applicable to a wide range of different concretes, from significantly low cement consumption ones $\left(126.9 \mathrm{~kg} / \mathrm{cm}^{3}\right)$ to ultra-high performance concretes $\left(896.3 \mathrm{~kg} / \mathrm{cm}^{3}\right)$. Regarding the Modified A\&A packing model, the distribution modulus values used in these works to optimize the concrete packing range from 0.16 to 0.4 .

Table 1: Studies from literature that used packing theory applied to concrete mixtures.

\begin{tabular}{|c|c|c|c|c|}
\hline & Authors & Cement $\left(\mathrm{kg} / \mathrm{m}^{3}\right)$ & Packing model & Distribution modulus (q) \\
\hline \multirow{10}{*}{ 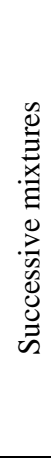 } & {$[17]$} & 312 & Fuller & - \\
\hline & {$[18]$} & 313.0 - 771.5 (25 values) & Modified A\&A & 0.3 \\
\hline & [9] & 410.04 & Modified A\&A & Not specified \\
\hline & [19] & $316,361,410$ & Modified A\&A & 0.35 \\
\hline & {$[8]$} & $266,277,326,341,380,401$ & Modified A\&A & $0.26,0.31,0.37$ \\
\hline & {$[20]$} & $354,519,684$ & Manual procedure & - \\
\hline & {$[21]$} & 420 & Manual procedure & - \\
\hline & {$[22]$} & $200,250,300,350$ & Manual procedure & - \\
\hline & {$[23]$} & 200 & Manual procedure & - \\
\hline & {$[31]$} & $434.06,358.1,347.25,325.54$ & Manual procedure & - \\
\hline \multirow{11}{*}{ 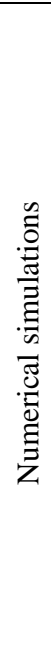 } & [24] & $212.3,239.5,245.0,290.0,310.0$ & Modified A\&A & $0.25,0.3,0.35,0.4$ \\
\hline & [7] & $637,675,712,750$ & Modified A\&A & 0.23 \\
\hline & [25] & 350 & Modified A\&A & 0.35 \\
\hline & [26] & $582.1-896.3$ (12 values) & Modified A\&A & 0.23 \\
\hline & [27] & 280 - 480 (15 values) & $\begin{array}{l}\text { 4-parameters compressible } \\
\text { packing model (CPM) }\end{array}$ & - \\
\hline & [5] & 126.9 - 213.8 (7 values) & Modified Westman \& Hugill & - \\
\hline & {$[28]$} & 279 & $\begin{array}{l}\text { Sequential particle packing } \\
\text { simulation algorithm (Sobolev } \\
\text { \& Amirjanov, 2004) }\end{array}$ & - \\
\hline & {$[34]$} & $466.7,362.3$ & Modified A\&A & 0.29 \\
\hline & {$[35]$} & $149,161,197,214,261,282$ & Modified A\&A & 0.21 e 0.37 \\
\hline & [33] & $\begin{array}{l}\text { 332.16, 364.74, 453.77, 439.75, } \\
607.35,420.82\end{array}$ & Modified A\&A & $0.16,0.23,0.27$ \\
\hline & [36] & $413.56,372.2,351.5,330.8$ & Modified A\&A & 0.35 \\
\hline
\end{tabular}


The studies cited in Table 1, regardless of the methodology used, have the same objective: to increase the efficiency of the binders, and thus, reduce the environmental impact, which include the decrease in $\mathrm{CO}_{2}$ emissions due to a lower cement content. The binder efficiency can be visualized by the ratio between the cement consumption in concrete and the compressive strength, which is called binder intensity (bi) [3]. Figure 1 shows the binder intensity considering the 28-day compressive strength of the different concrete mixtures mentioned in Table 1 . The $b i$ varied from $2.55 \mathrm{~kg} \cdot \mathrm{m}^{-3} / \mathrm{MPa}$ [17] to $15.2 \mathrm{~kg} \cdot \mathrm{m}^{-3} / \mathrm{MPa}$ [8]. The studies highlighted in Figure 1, [17-35], presented the lowest bi values among all mixtures. These works used different distribution modulus for the fine and coarse materials, and higher energy mixers, which improves the dispersion of the particles. [35]. The behavior observed in Figure 1 shows that it is possible to produce concretes of the same compressive strength class with different cement contents and thus increase the binder efficiency for those with lower cement content.

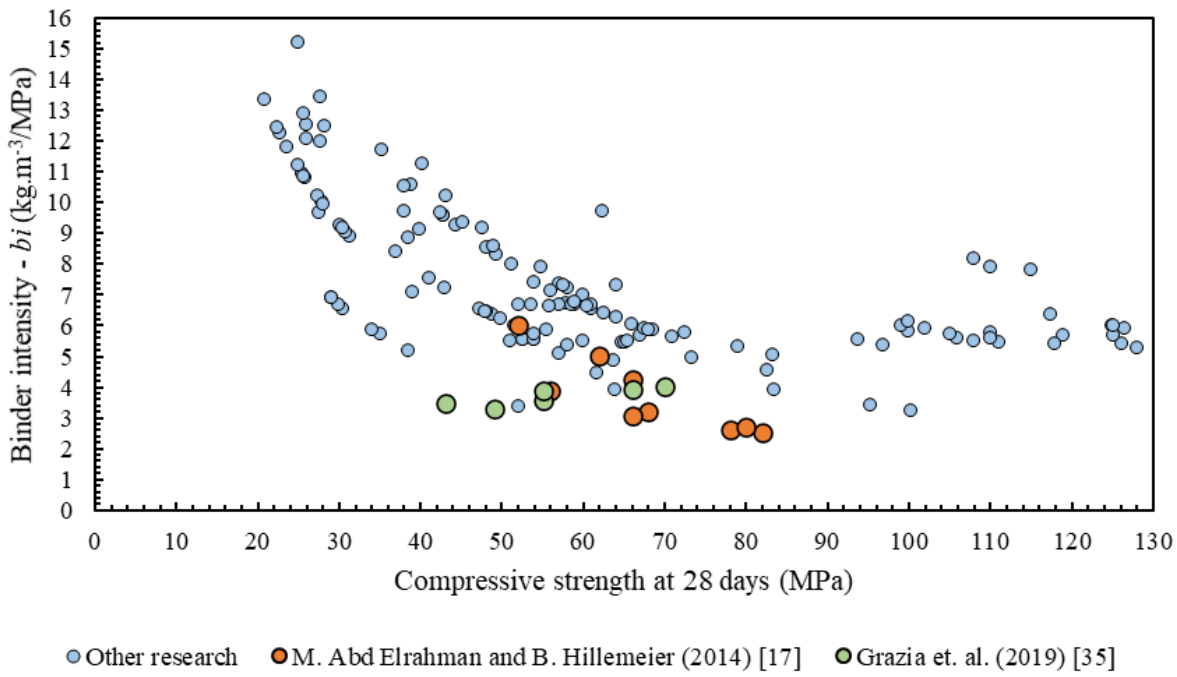

Figure 1: Relationship between binder intensity (bi) and compressive strength at 28 days for the studies presented in Table 1.

\subsection{Scope of work}

In the context of eco-efficient concretes which requires satisfactory performance without increasing cement content, the present work shows the use of a practical numerical simulation to enhance aggregate skeleton packing. A first aim of this work is to present a methodology for packing analysis in which linear programming is used to save time and materials. For that, the modified A\&A model was selected due to its simplicity in input parameters (aggregate particle size distributions (PSD) and distribution modulus "q") and non-robust calculations. The used methodology identifies the best aggregate proportions which minimizes the distance between the experimental PSD curve and the mathematical PSD curve from the modified A\&A packing model. Moreover, the effect of aggregate size and deviations between PSD curves are discussed in each step of the process and related to the final void content measurements. The applicability of the modified A\&A model to non-spherical particles was made through granulometric analysis of the experimental (real) mixtures, in which the proportions of the materials were obtained through the optimization proposed in this work.

This methodology is mainly used in high performance concrete mix design. Particle packing for regular concretes, however, is still limited, in most cases, to a simple optimization of the granular skeleton of aggregates by the successive mixtures method. Another objective of this work is the mixture design of concretes using the optimized proportions of their constituent materials associated with the partial cement replacement by a ground waste from heavy ceramic industry without loss of mechanical performance. The mix design is presented in a simplified way: particle grain size and specific mass data $\rightarrow$ computational tool through linear programming, which enables the selection of $n$ aggregates or particle size classes (fine and coarse) $\rightarrow$ optimized aggregate proportions $\rightarrow$ determination of binder consumption or paste volume $\rightarrow$ partial replacement of cement by ground waste from heavy ceramic industry $\rightarrow$ concrete mixture. 


\section{MATERIALS AND METHODS}

\subsection{Granular skeleton optimization}

Numerical simulations were performed to reduce the void content of concrete granular skeletons. The optimization algorithm included the modified A\&A model (3), the least squares method (4) (presented in section 2.2) and the particle size data from the aggregates. Figure 2 summarizes the needed input and generated output data through each step of the process, which is detailed in the next sections.

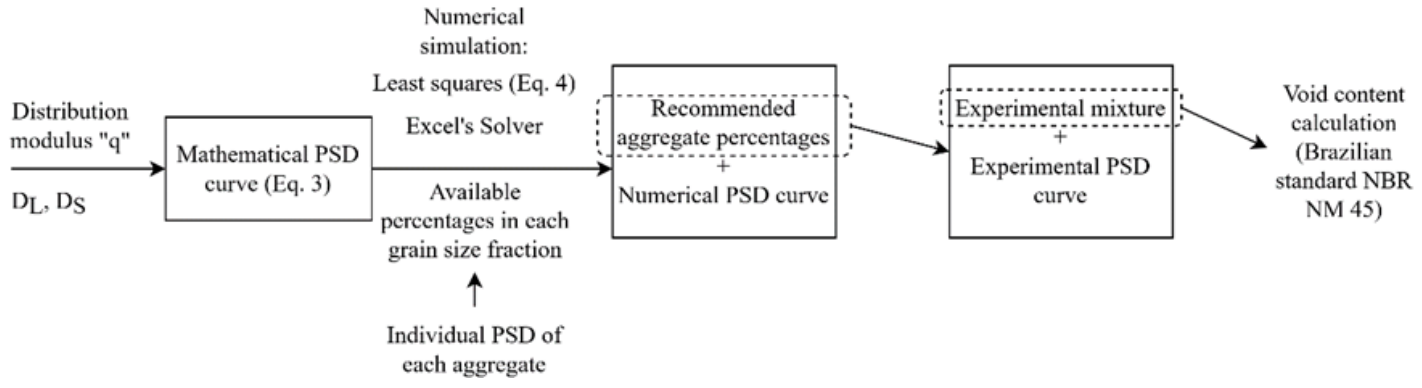

Figure 2: Input and output data in the optimization of PSD curves.

\subsubsection{Aggregates}

Two different batches of aggregates (river sand and granite gravel) were used in this work. The sand was separated in three fractions: fine (diameter $<0.6 \mathrm{~mm})$, medium $(0.6 \mathrm{~mm}<$ diameter $<1.2 \mathrm{~mm})$ and coarse (diameter $>1.2 \mathrm{~mm}$ ). The gravels used were gravel 1 with maximum diameter of $12.5 \mathrm{~mm}$ and gravel 2 with maximum diameter of $19 \mathrm{~mm}$. Figures 3 and 4 show the cumulative and discrete PSD curves of each aggregate batch. Their grain size information was obtained through the granulometric analysis of the aggregates carried out by sieving, which followed the [29] recommendations.
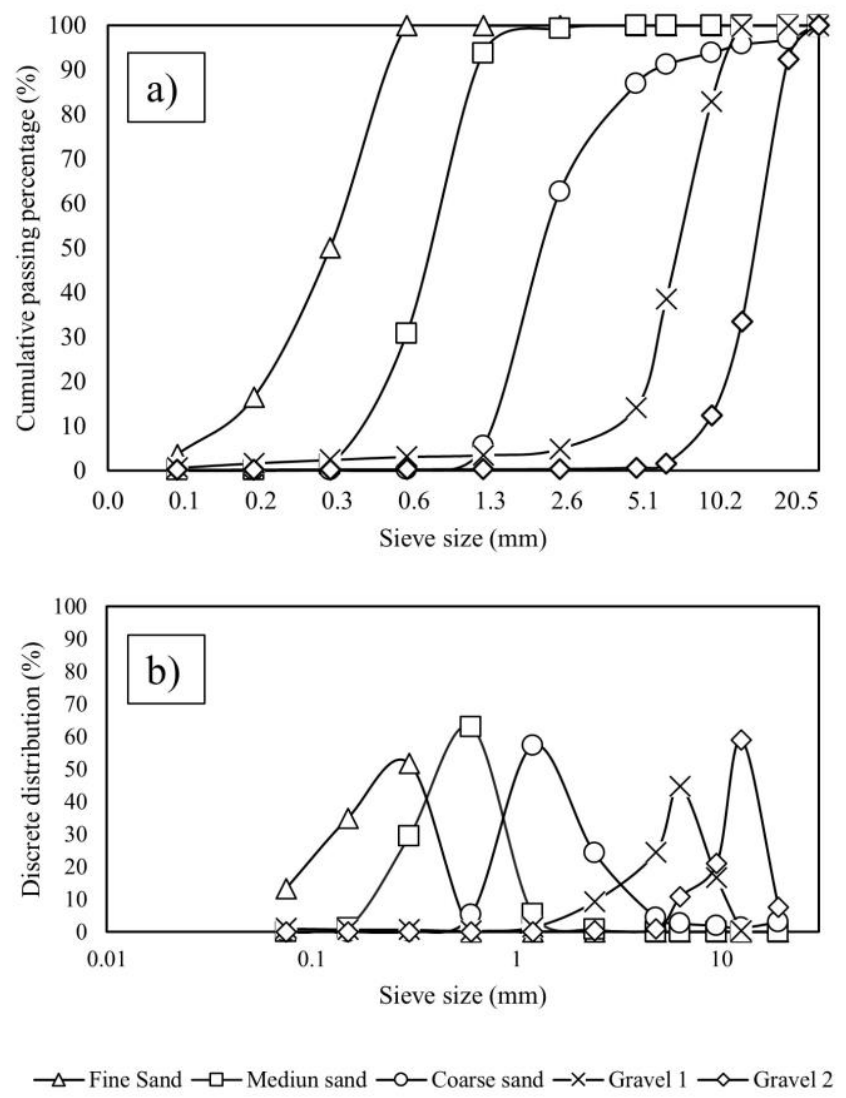

Figure 3: Cumulative and discrete PSD curves of aggregates - batch 1 . 

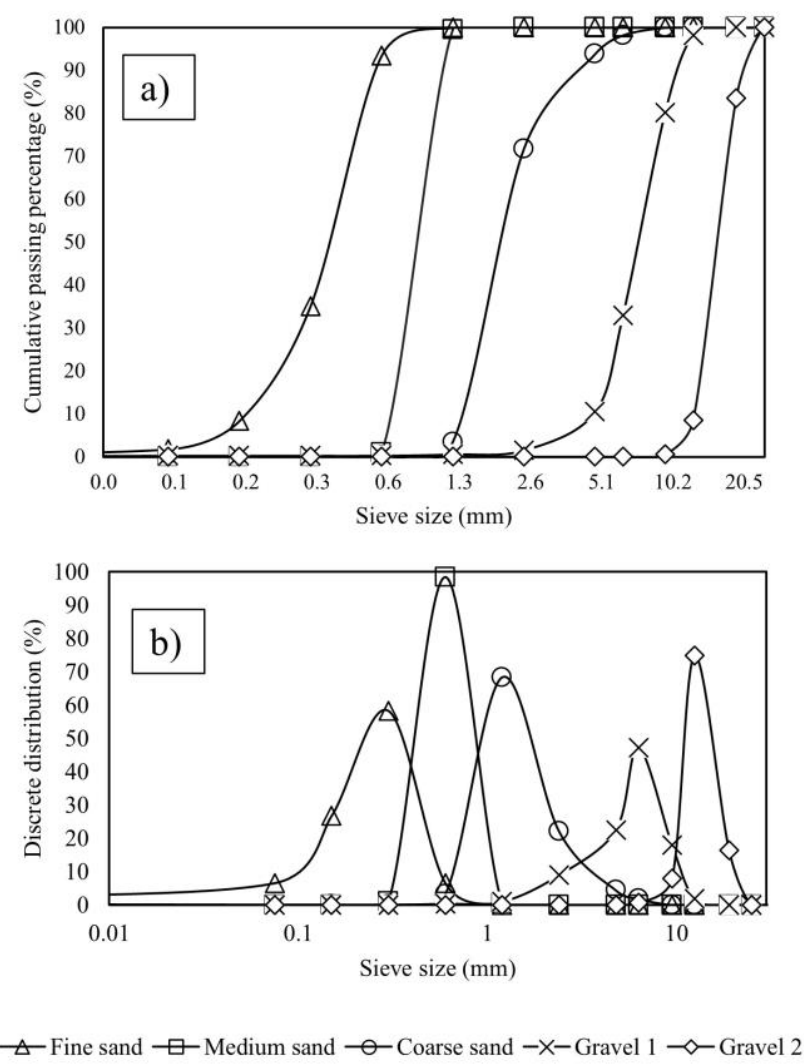

Figure 4: Cumulative and discrete PSD curves of aggregates - batch 2 .

As can be seen in Figures 3 and 4, the used aggregates show complementary particle size distributions, which make easier the packing procedures. Furthermore, there is a significant difference between the particle diameters from batch 1 and batch 2 , as shown in their respective discrete distributions.

\subsubsection{Numerical simulations}

To obtain the mathematical PSD curves, the modified A\&A packing model (3) was used. The input data were the distribution modulus "q", the largest and the smallest aggregate diameter $\left(\mathrm{D}_{\mathrm{L}}\right.$ and $\mathrm{D}_{\mathrm{S}}$, respectively) in batches 1 and 2. $D_{L}$ and $D_{S}$ were fixed values of $19 \mathrm{~mm}$ and $0.075 \mathrm{~mm}$, respectively, which were obtained from the granulometric analysis of the aggregates. A broad range of q values was tested in this first stage: 0.1 - 0.6. As the input diameters were fixed, for each $q$ value tested a different curve-response was obtained.

Then, numerical simulations were performed in Microsoft Excel spreadsheets to generate the numerical PSD curves. The optimization algorithm was a combination of the least squares method and Excel's Solver command. Using the individual PSD of each aggregate, the simulations calculated the optimal aggregate percentages required to plot a numerical PSD curve with minimum deviation to its respective mathematical PSD curve. This deviation was calculated through (5) and minimized by the Solver command.

In Table 2 is presented the mathematical solution to the case of a mixture with " $m$ " aggregates and " $n$ " sieves/particle size classes. 
Table 2: Calculation process of the deviation (RSS) between the numerical and the mathematical PSD curves for a mixture with $\mathrm{m}$ aggregates.

\begin{tabular}{|c|c|c|c|c|c|c|c|}
\hline$\Phi$ & pe $(\%)$ & $\mathrm{pa}_{1}(\%)$ & $\mathrm{pa}_{2}(\%)$ & $\ldots$ & $\mathrm{pa}_{\mathrm{m}}(\%)$ & $\mathrm{pc}(\%)$ & $\Delta$ \\
\hline$\Phi_{1}$ & $\mathrm{pe}_{1}$ & $\mathrm{pa}_{1,1}$ & $\mathrm{pa}_{2,1}$ & $\cdots$ & $\mathrm{pa}_{\mathrm{m}, 1}$ & $\mathrm{pc}_{1}$ & $\Delta_{1}=\mathrm{pc}_{1}-\mathrm{pe}_{1}$ \\
\hline$\Phi_{2}$ & $\mathrm{pe}_{2}$ & $\mathrm{pa}_{1,2}$ & $\mathrm{pa}_{2,2}$ & $\ldots$ & $\mathrm{pa}_{\mathrm{m}, 2}$ & $\mathrm{pc}_{2}$ & $\Delta_{2}=\mathrm{pc}_{2}-\mathrm{pe}_{2}$ \\
\hline ... & $\ldots$ & ... & $\ldots$ & $\ldots$ & $\ldots$ & $\cdots$ & \\
\hline$\Phi_{\mathrm{n}}$ & $\mathrm{pe}_{\mathrm{n}}$ & $\mathrm{pa}_{1, \mathrm{n}}$ & $\mathrm{pa}_{2, \mathrm{n}}$ & $\ldots$ & $\mathrm{pa}_{\mathrm{m}, \mathrm{n}}$ & $\mathrm{pc}_{\mathrm{n}}$ & $\Delta_{\mathrm{n}}=\mathrm{pc}_{\mathrm{n}}-\mathrm{pe}_{\mathrm{n}}$ \\
\hline \multicolumn{7}{|c|}{ RSS } & $\sum \Delta_{\mathrm{i}}^{2}$ \\
\hline
\end{tabular}

Where:

$\Phi_{i}-$ Sieve/particle size class "i";

$\mathrm{pe}_{\mathrm{i}}$ - Accumulated retained percentage in sieve "i", calculated by the modified A\&A packing model;

$\mathrm{pa}_{\mathrm{j}, \mathrm{i}}$ - Accumulated retained percentage in sieve " $\mathrm{i}$ " for aggregate $\mathrm{a}_{\mathrm{j}}$;

$\mathrm{pc}_{\mathrm{i}}$ - Accumulated retained percentage in sieve " $\mathrm{i}$ " for the combination of aggregates $1,2, \ldots, \mathrm{m}$;

$\Delta_{\mathrm{i}}$ - Deviation between the accumulated percentage of aggregates retained in sieve " $\mathrm{i}$ " and its respective recommended accumulated retained percentage by the mathematical model;

RSS - Deviation between the numerical PSD and the mathematical PSD, calculated as a residual sum of squares, where: $\mathrm{i}$ varies from 1 to $\mathrm{n}$, and $\mathrm{j}$ varies from 1 to $\mathrm{m}$.

In matrix form, the accumulated retained percentages of the combined aggregates for each sieve can be written as shown in equation 4.

$$
\left[\mathrm{pa}_{\mathrm{j}, \mathrm{i}}\right]_{\mathrm{nxm}} \cdot\left[\beta_{\mathrm{j}}\right]_{\mathrm{mx} 1}=\left[\mathrm{pc}_{\mathrm{i}}\right]_{\mathrm{nx} 1} \Rightarrow\left[\begin{array}{cccc}
\mathrm{pa}_{1,1} & \mathrm{pa}_{2,1} & \ldots & \mathrm{pa} \mathrm{m}_{\mathrm{m}, 1} \\
\mathrm{pa}_{1,2} & \mathrm{pa}_{2,2} & \ldots & \mathrm{pa} \mathrm{m}_{\mathrm{m}, 2} \\
\ldots & \ldots & \ldots & \ldots \\
\mathrm{pa}_{1, \mathrm{n}} & \mathrm{pa}_{2, \mathrm{n}} & \ldots & \mathrm{pa}_{\mathrm{m}, \mathrm{n}}
\end{array}\right] \cdot\left[\begin{array}{c}
\beta_{1} \\
\beta_{2} \\
\ldots \\
\beta_{\mathrm{m}}
\end{array}\right]=\left[\begin{array}{c}
\mathrm{pc}_{1} \\
\mathrm{pc}_{2} \\
\ldots \\
\mathrm{pc}_{\mathrm{n}}
\end{array}\right]
$$

Where: $\beta_{\mathrm{j}}$ is the percentage of aggregate $\mathrm{a}_{\mathrm{j}}$ in the combination.

The packing optimization is performed through linear programming, in which the objective function to be minimized corresponds to the RSS (5), and the imposed restriction is $\sum_{1}^{\mathrm{m}} \beta_{\mathrm{j}}=100 \%$. Therefore, the optimization consists in varying the coefficients $\beta \mathrm{j}$ until a minimum RSS value is found.

$$
\mathrm{RSS}=\sum_{1}^{\mathrm{n}} \Delta_{\mathrm{i}}^{2}=\frac{\left(\mathrm{pc}_{\mathrm{i}}-\mathrm{pe}_{\mathrm{i}}\right)^{2}}{100}
$$

Where:

$\mathrm{pe}_{\mathrm{i}}=\frac{\mathrm{D}_{\mathrm{i}}{ }^{\mathrm{q}}-\mathrm{D}_{\mathrm{S}}{ }^{\mathrm{q}}}{\mathrm{D}_{\mathrm{L}}{ }^{\mathrm{q}}-\mathrm{D}_{\mathrm{S}}{ }^{\mathrm{q}}} \times 100$ (Modified A\&A model)

$\mathrm{pc}_{\mathrm{i}}=\sum_{\mathrm{j}}^{\mathrm{m}} \beta_{\mathrm{j}} \mathrm{pa}_{\mathrm{j}, \mathrm{i}}$

After this, the recommended aggregate percentages $\beta_{\mathrm{j}}$ were used to compose the experimental mixtures in laboratory. This was made for mixtures with q values of $0.2,0.25,0.3,0.35$ and 0.4 , on both aggregate batches. These values were chosen because they represent a broad range of the optimum q values recommended in literature [7, 8, 18, 19, 24-26].

The void content of each mixture was then calculated according to (6), (7) and (8), as recommended by the Brazilian standard [30]. Three samples were made for each recommended mixture. The bulk density was calculated experimentally, and the specific density was the weighted average specific density of each component of the mixture. A two-way Analysis of Variance (ANOVA) was performed to test the significance of the independent variables (aggregate batch and distribution modulus "q") on the dependent variable (void content).

$$
\begin{gathered}
\rho_{\text {mix }}=\left(\rho_{\mathrm{ag}_{1}} \times \% \mathrm{ag}_{1}+\rho_{\mathrm{ag}_{2}} \times \% \mathrm{ag}_{2}+\cdots \rho_{\mathrm{ag}_{\mathrm{n}}} \times \% \mathrm{ag}_{\mathrm{n}}\right) \times 100 \\
\mathrm{~d}_{\text {mix }}=\frac{\mathrm{M}_{\text {mix }}}{\mathrm{V}_{\text {mix }}}
\end{gathered}
$$




$$
\operatorname{Void}(\%)=\left(\frac{\rho_{\text {mix }}-\mathrm{d}_{\text {mix }}}{\rho_{\text {mix }}}\right) \times 100
$$

Where $\rho$ is the specific mass, mix is the mixture, \%agn is the percentage of aggregate $\mathrm{n}, \mathrm{d}$ is the bulk density, $\mathrm{M}$ is the mass and $\mathrm{V}$ is the volume.

The deviations between the experimental-mathematical, experimental-numerical, and numericalmathematical curves were also calculated by (5) and compared to their respective void content values. In this work, the mathematical curves are those obtained from the modified A\&A model (3), numerical curves are those that, starting from the particle size distribution of each aggregate, come closest to the mathematical curves, and experimental ones are those obtained from the mixture of aggregates in laboratory using the recommended percentages of the numerical curves.

\subsection{Concrete mixtures design}

The first step in obtaining concrete mixtures was the definition of the optimal proportion between the aggregates, as explained in section 2.1.

From the results of the numerical simulations and experimental mixtures, two levels of the distribution modulus q were chosen: 0.25 and 0.35 . The used aggregates were from batch 2 (Figure 4 ), due to the lower voids content obtained in this batch.

The second step was the definition of the cement and the waste material (used as Portland cement replacement) contents, the water to fines ratio and thus the concrete formulations.

The used cement was a Brazilian high early strength Portland cement (CPV ARI), with specific mass of 3.11 $\mathrm{g} / \mathrm{cm}^{3}$. It was chosen due to its high level of clinker content. A ground clay brick waste (GCBW) from a local ceramic industry was used as partial cement replacement. Its specific mass was $2.61 \mathrm{~g} / \mathrm{cm}^{3}$ and its milling procedure is fully described in [40]. This industrial waste was chosen due to the high volume generation of bricks waste in the region where this study was carried out, which is a consequence of the heavy ceramic industry being an strong industrial segment in Paraíba state [40]. Table 3 and Figure 5 present the chemical composition and the particle size distribution of GCBW and CPV. In Figure 5, it can be seen a contribution of GCBW in granulometry zones were cement present lower contents (particles smaller than $3 \mu \mathrm{m}$ and higher than $50 \mu \mathrm{m})$.

Table 3: Chemical composition of GCBW and cement CPV

\begin{tabular}{|c|c|c|c|c|c|c|c|c|c|c|c|c|c|}
\hline \multicolumn{13}{|c|}{ Oxide content (\%) } & \multirow{2}{*}{$\begin{array}{l}\bar{\sigma} \\
\frac{\sigma}{2} \\
\bar{\Phi} \\
\Sigma\end{array}$} \\
\hline $\mathrm{SiO}_{2}$ & $\mathrm{Al}_{2} \mathrm{O}_{3}$ & $\mathrm{Fe}_{2} \mathrm{O}_{3}$ & $\mathrm{MgO}$ & $\mathrm{K}_{2} \mathrm{O}$ & $\mathrm{Na}_{2} \mathrm{O}$ & $\mathrm{TiO}_{2}$ & $\mathrm{CaO}$ & $\mathrm{BaO}$ & $\mathbf{P}_{2} \mathrm{O}_{5}$ & $\mathrm{SO}_{3}$ & MnO & $\mathrm{ZrO}_{2}$ & \\
\hline 64.24 & 18.25 & 9.68 & 1.82 & 1.65 & 1.40 & 1.10 & 0.86 & 0.28 & 0.19 & 0.15 & 0.14 & 0.09 & GCBW \\
\hline 22.11 & 3.99 & 3.41 & 1.97 & 0.96 & 0.43 & 0.37 & 62.25 & 0.09 & 0.64 & 3.51 & 0.03 & - & $\mathrm{CPV}$ \\
\hline
\end{tabular}

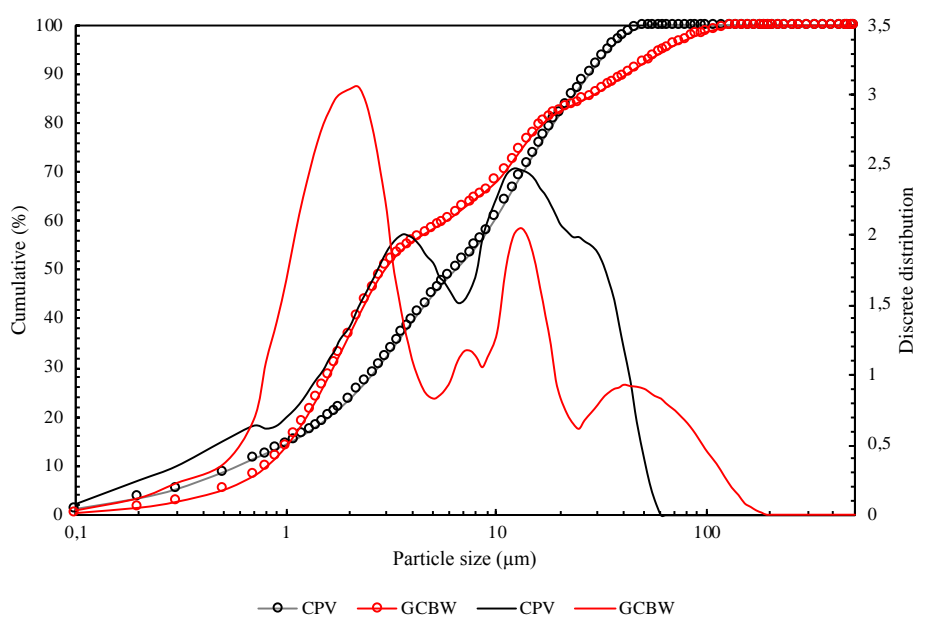

Figure 5: Particle size distribution of the cement CPV and GCBW. 
The concrete mixtures adopted in this work are shown in Table 4. The reference mix (REF) was not defined using packing procedures, but instead, a conventional concrete composition with $430 \mathrm{~kg} / \mathrm{m}^{3}$ of cement was adopted. The other concrete mixtures were defined in two levels of packing, upper (SQ) and intermediate (IQ), with 5 and 4 aggregates, respectively, and two levels of distribution modulus q, 0.25 and 0.35 , which are reflected on concrete codes informed in Table 4 . The substitution of $50 \%$ of cement by GCBW was adopted for all optimized mixtures and a constant ratio of 0.45 between water and fines (cement and GCBW) was set for all concretes.

Table 4: Concrete mixtures.

\begin{tabular}{|c|c|c|c|c|c|c|c|c|}
\hline Concrete & $\begin{array}{l}\text { Cement } \\
\left(\mathrm{kg} / \mathrm{m}^{3}\right)\end{array}$ & $\begin{array}{l}\text { GCBW } \\
\left(\mathrm{kg} / \mathrm{m}^{3}\right)\end{array}$ & $\begin{array}{l}\text { Fine Sand } \\
\qquad\left(\mathrm{kg} / \mathrm{m}^{3}\right)\end{array}$ & $\begin{array}{c}\text { Medium } \\
\text { Sand } \\
\left(\mathrm{kg} / \mathrm{m}^{3}\right) \\
\end{array}$ & $\begin{array}{c}\text { Coarse } \\
\text { Sand } \\
\left(\mathrm{kg} / \mathrm{m}^{3}\right)\end{array}$ & $\begin{array}{c}\text { Gravel } 1 \\
\left(\mathrm{~kg} / \mathrm{m}^{3}\right)\end{array}$ & $\begin{array}{c}\text { Gravel } 2 \\
\left(\mathrm{~kg} / \mathrm{m}^{3}\right)\end{array}$ & $\begin{array}{l}\text { Water } \\
\left(\mathrm{kg} / \mathrm{m}^{3}\right)\end{array}$ \\
\hline SQ2550 & 215 & 215 & 431.4 & 114.6 & 422.4 & 464.0 & 313.7 & 193.5 \\
\hline SQ3550 & 215 & 215 & 337.3 & 106.7 & 413.7 & 511.2 & 377.7 & 193.5 \\
\hline IQ2550 & 215 & 215 & 482.6 & - & 506.4 & 454.4 & 303.1 & 193.5 \\
\hline IQ3550 & 215 & 215 & 384.6 & - & 493.7 & 503.1 & 365.4 & 193.5 \\
\hline REF & 430 & - & - & 798.8 & - & - & 966.3 & 193.5 \\
\hline
\end{tabular}

Figure 6 shows the percentage of each constituent material in the concrete mixtures, where the differences in adopting an upper or intermediate packing, as well as a distribution modulus of 0.25 or 0.35 , can be easily seen.

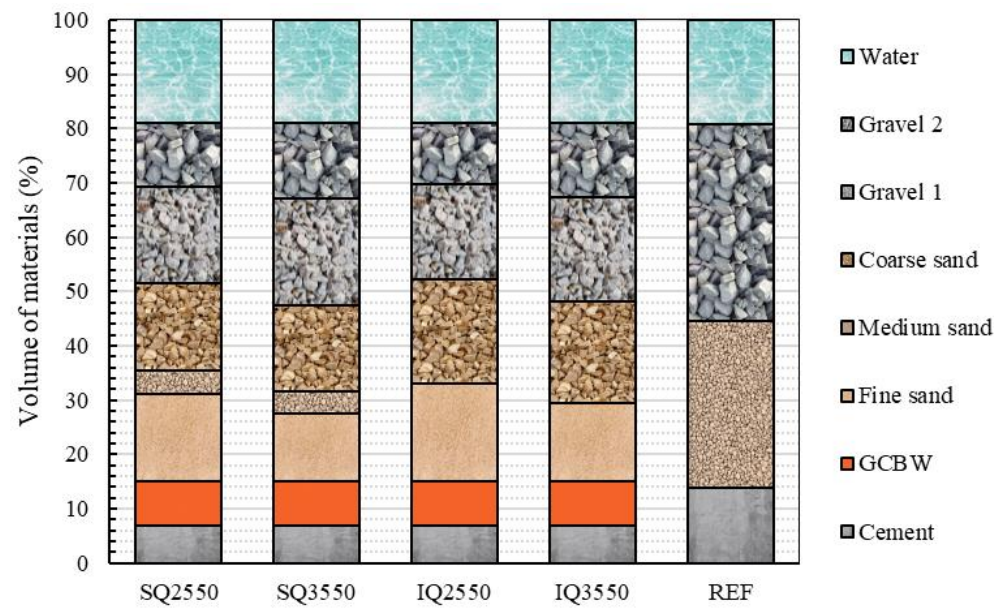

Figure 6: Relative volume of each material on concrete mixtures.

The concretes were mixed in a concrete mixer with capacity of 320 liters and rotation speed of $30 \mathrm{rpm}$. Then, cylindrical molds were used to cast concrete specimens $(10 \times 20 \mathrm{~cm})$. After being cast, all concrete specimens were cured in a wet chamber for 7, 28 and 91 days and afterwards were made available for testing. Slump test in fresh state and compressive strength at 7,28 and 91 days in hard state were the tests carried out with the studied concretes. All of them followed the Brazilian standards recommendations.

\section{RESULTS AND DISCUSSION}

\subsection{Granular skeleton}

\subsubsection{Effect of aggregate size}

Using the numerical simulations described in section 2 to generate numerical PSD curves, by increasing the distribution modulus " $q$ " values, it was possible to observe a decreasing linear trend of fine aggregate content (Figure 7). Higher q values leads to coarser mixtures, while smaller q values leads to mixtures rich in fine particles [24]. As the fine aggregate content directly influences the workability of the concrete, the adequate value of the distribution modulus in (3) may vary depending on the application requirements. 


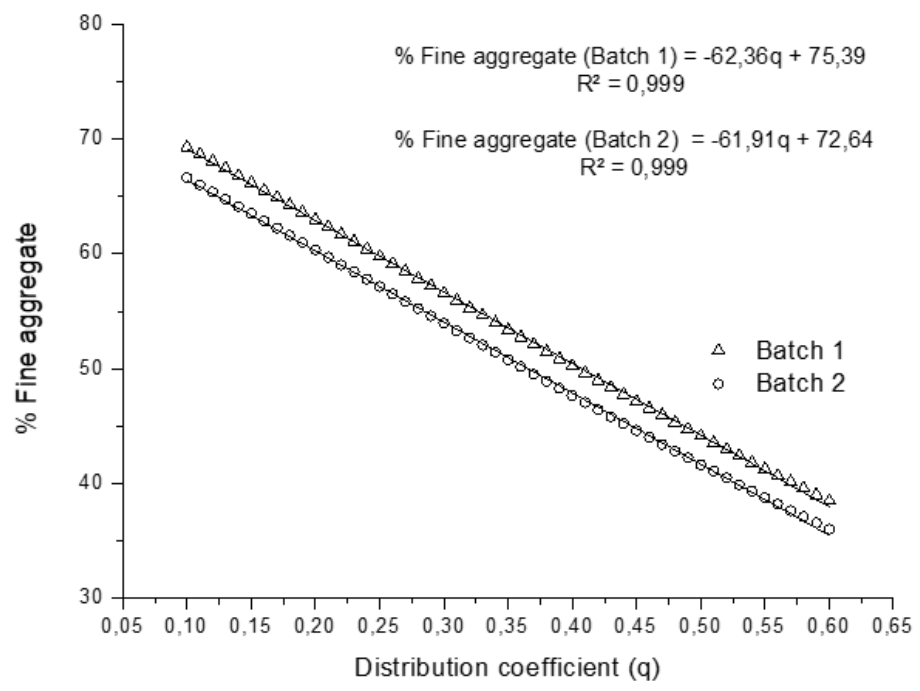

Figure 7: Relationship between fine aggregate content and distribution modulus (q).

The deviations between the numerical and mathematical PSD curves are presented in Figure 8. Lower total deviations (Batch 1 and Batch 2 series) were found for higher q values, with stabilization trend after $q$ values higher than 0.35. In general, for q values greater than 0.35 , the total deviation trend (Figure 8 ) and the fine aggregate content trend (Figure 7) diverge, since the first one tends to stabilize and the last one has a continuous linear decrease behavior. As discussed, mixtures with lower q values are richer in fine aggregate content (Figure 7). Moreover, sand is the top contributor in the overall deviation values until $\mathrm{q}=0.47$ (Batch 2) or $q=0.60$ (Batch 1). Therefore, when the sand content decreases, these deviations tend to also decrease.

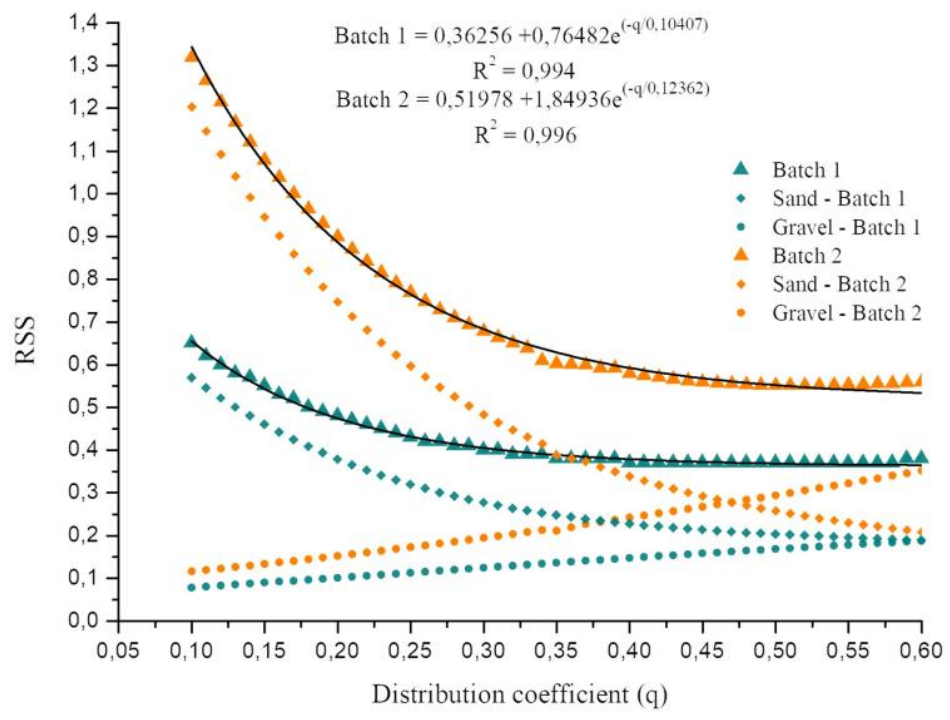

Figure 8: Deviations (RSS) between numerical and mathematical PSD curves.

\subsubsection{Experimental mixtures}

After the numerical simulations were performed, experimental mixtures were made using the recommended aggregate compositions from their respective numerical PSD curves. This was made for mixtures with q values of $0.20,0.25,0.30,0.35$ and 0.40 . Using (6), (7) and (8), it was possible to calculate the void content of those mixtures (Table 5). 
Table 5: Distribution modulus, deviations, experimental mixture compositions and void indexes.

\begin{tabular}{|c|c|c|c|c|c|c|c|c|}
\hline \multirow[b]{2}{*}{$\begin{array}{l}\text { Distribution } \\
\text { modulus "q" }\end{array}$} & \multirow[b]{2}{*}{ Deviations* } & \multicolumn{5}{|c|}{ Numerical mixture (\%) } & \multicolumn{2}{|c|}{ Experimental results } \\
\hline & & 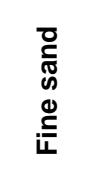 & 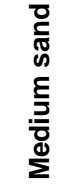 & 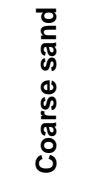 & $\begin{array}{l}0 \\
\frac{0}{0} \\
\frac{\pi}{0}\end{array}$ & $\frac{\bar{\Phi}}{\frac{\pi}{\mathbb{N}}}$ & $\begin{array}{l}\text { Unit weight } \\
\left(\mathbf{g} / \mathrm{cm}^{3}\right)\end{array}$ & Void content (\%) \\
\hline \multicolumn{9}{|c|}{ Batch 1} \\
\hline 0.20 & 0.48 & 24.87 & 7.92 & 20.21 & 21.98 & 15.02 & 1.79 & 32.46 \\
\hline 0.25 & 0.43 & 21.75 & 7.93 & 30.10 & 23.32 & 16.89 & 1.80 & 32.19 \\
\hline 0.30 & 0.40 & 18.89 & 7.82 & 29.85 & 24.57 & 18.86 & 1,80 & 32.21 \\
\hline 0.35 & 0.38 & 16.30 & 7.60 & 29.47 & 25.73 & 20.89 & 1.71 & 35.41 \\
\hline 0.40 & 0.37 & 13.97 & 7.30 & 28.96 & 26.78 & 23.00 & 1.69 & 36.19 \\
\hline \multicolumn{9}{|c|}{ Batch 2} \\
\hline 0.20 & 0.90 & 29.66 & 4.87 & 25.81 & 27.02 & 12.64 & 1.91 & 28.45 \\
\hline 0.25 & 0.77 & 26.42 & 4.94 & 25.79 & 28.80 & 14.05 & 1.92 & 28.15 \\
\hline 0.30 & 0.68 & 23.41 & 4.93 & 25.61 & 30.52 & 15.53 & 2.00 & 25.22 \\
\hline 0.35 & 0.62 & 20.64 & 4.85 & 25.29 & 32.16 & 17.06 & 1.95 & 27.17 \\
\hline 0.40 & 0.58 & 18.11 & 4.70 & 24.84 & 33.71 & 18.64 & 1.90 & 29.10 \\
\hline
\end{tabular}

Figure 9 shows the void content versus distribution modulus plot. As shown, a tendency of increasing void content is seen as the distribution modulus increases from 0.30 to 0.40 . The minimum void content was observed for a distribution modulus (q) of 0.3 .

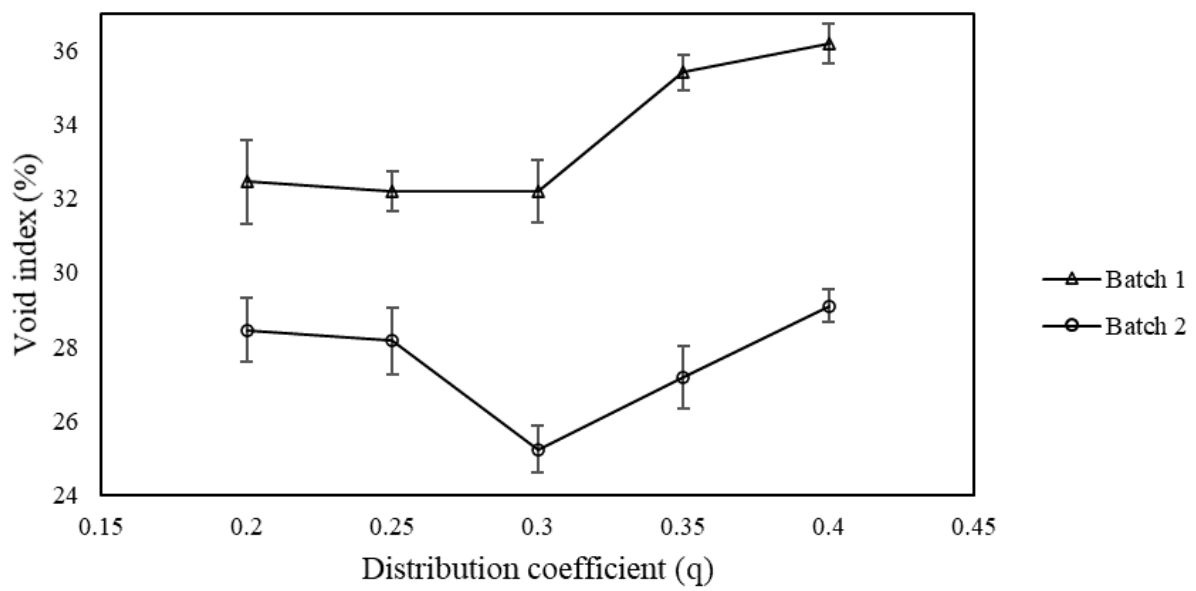

Figure 9: Relationship between void content and distribution modulus (q).

A two-way ANOVA tested the influence of two independent variables (aggregate batch and distribution modulus "q") on the void content. It was confirmed that there was significant $(p<0.05)$ difference between the aggregate batches, between $q$ values, and between aggregate batches and q values (Table 6), and thus, they influence the void content. Duncan's Multiple Range Test was also performed and ascertained significant difference between all levels of q values and between the two studied batches. 
Table 6: Two-way ANOVA test report. Independent variables: aggregate batch and distribution modulus " $\mathrm{q}$ ”. Dependent variable: void content.

\begin{tabular}{l|c|c|c|c|c|c|c}
\hline \multicolumn{1}{c}{$\begin{array}{c}\text { Dependent } \\
\text { variables }\end{array}$} & $\begin{array}{c}\text { Sum of } \\
\text { squares }\end{array}$ & $\begin{array}{c}\text { Degrees of } \\
\text { freedom }\end{array}$ & $\begin{array}{c}\text { Mean } \\
\text { squares }\end{array}$ & F-value & P-value & F crit & Contribution (\%) \\
\hline $\begin{array}{l}\text { Between aggregate } \\
\text { batches }\end{array}$ & 276.701 & 1 & 276.70 & 470.852 & $2.26 \mathrm{E}-15$ & 4.351 & 76.58 \\
\hline Between q values & 50.413 & 4 & 12.60 & 21.446 & $5.32 \mathrm{E}-07$ & 2.866 & 13.95 \\
\hline $\begin{array}{l}\text { Between aggregate } \\
\text { batches and q values }\end{array}$ & 22.440 & 4 & 5.61 & 9.546 & 0.000174 & 2.866 & 6.21 \\
\hline Error & 11.753 & 20 & 0.59 & & & & 3.25 \\
\hline
\end{tabular}

A maximum suitable distribution modulus is in line with the results from Funk \& Dinger's computational simulations, which showed that $q$ values equal or lower than 0.37 favors maximum packing of infinite particle distributions, whereas q values higher than 0.37 results in mixtures with higher residual porosity [12]. The difference in the maximum recommended q values for this study (0.30) and Funk and Dinger's (0.37) may be because of the morphology of the particles. Their study used spherical shape particles, and the present one used real sand and gravel, which have irregular shapes.

Figure 10 shows the deviations from the experimental mixtures and the mathematical or numerical PSD curves. As expected, deviations between the mathematical and experimental PSD curves are higher than deviations between the mathematical and numerical PSD curves. This can be explained by the fact that the modified A\&A model does not consider parameters such as the shape or the texture of the aggregates, and thus, more errors are introduced when the experimental mixture is composed. However, these deviations were not enough to affect the accuracy of the numerical simulations of this study.

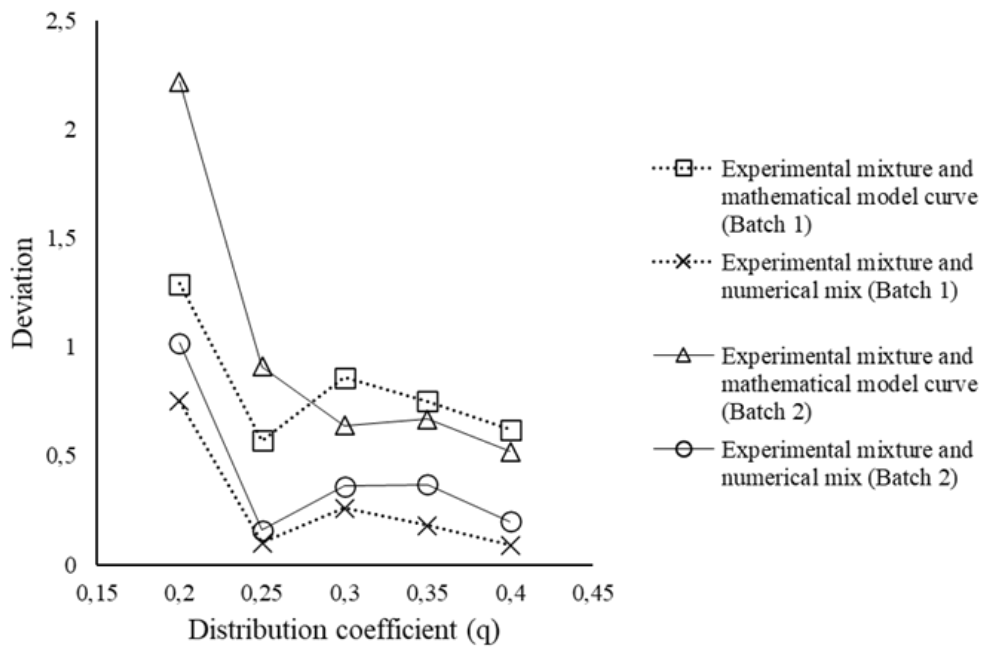

Figure 10: Deviations between experimental mixtures and mathematical or numerical PSD curves. 
Figures 11 and 12 shows the mathematical, numerical and experimental PSD curves for each value of distribution modulus used. Aside from the visual proximity between the curves, it can be noticed that all $\mathrm{R}^{2}$ values between the numerical and experimental PSD curves are higher than 0.99, indicating that the experimental data has very high predictability by the numerical simulations.
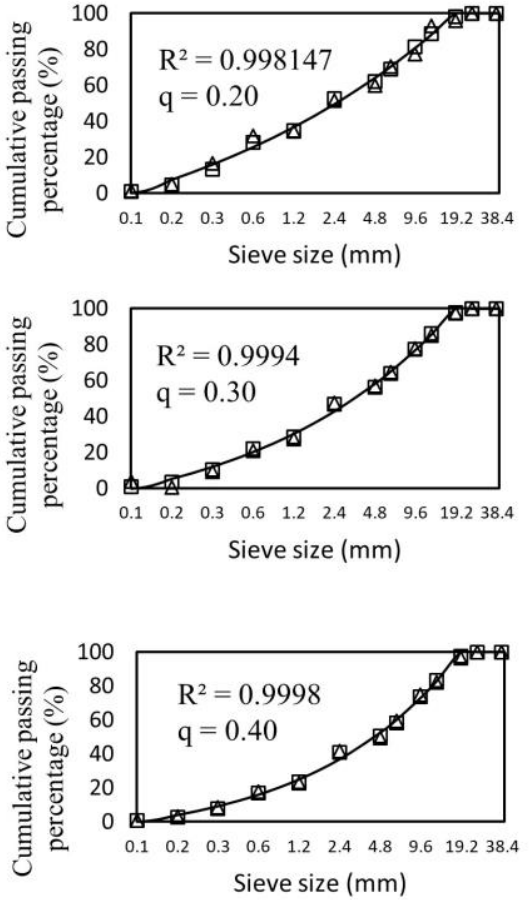
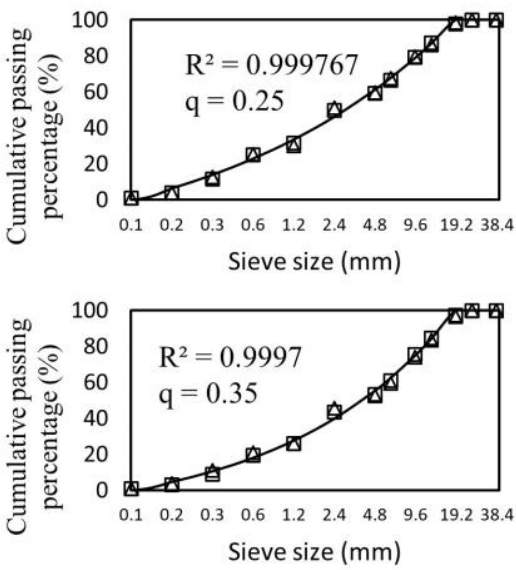

Numerical mixture curve (Batch 1)

— Mathematical model curve (Modified A\&A model) (Batch 1)

$\Delta$ Experimental mixture curve (Batch 1)

The $\mathrm{R}^{2}$ was calculated between the numerical and experimental mixture curves.

Figure 11: Mathematical, analytical, and experimental PSD curves of aggregates batch 1.
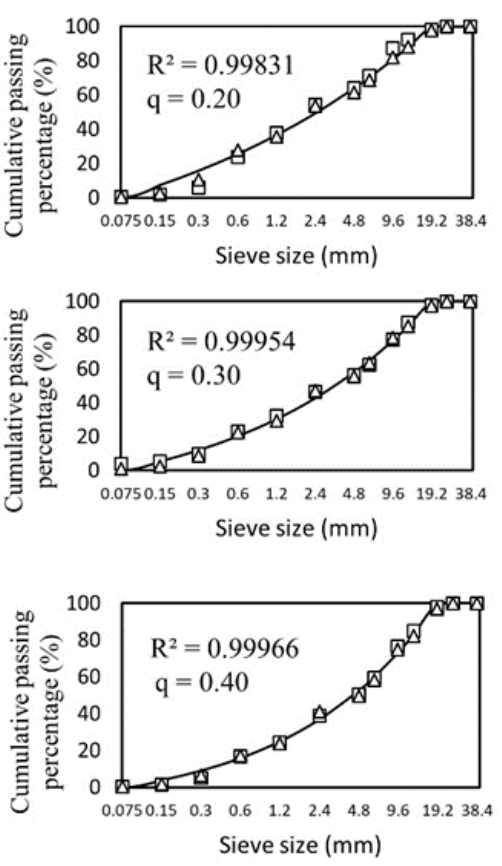
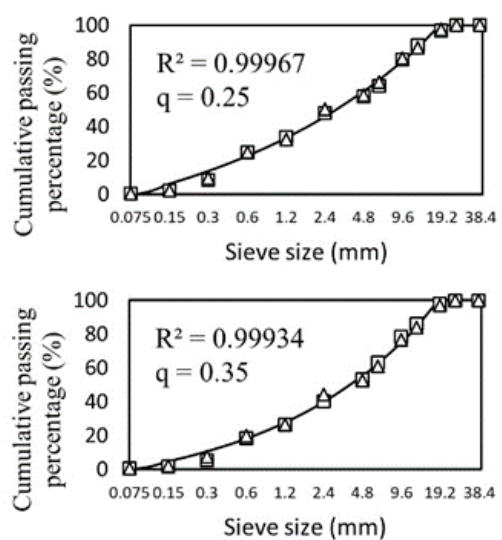

ㅁ Numerical mixture curve (Batch 2)

- Mathematical model curve (Modified A\&A model) (Batch 2)

$\Delta$ Experimental mixture curve (Batch 2)

The $\mathrm{R}^{2}$ was calculated between the numerical and experimental mixture curves.

Figure 12: Mathematical, analytical, and experimental PSD curves of aggregates batch 2 . 


\subsubsection{General analysis}

An aggregate granular skeleton with minimum void content is important to design eco-efficient concrete mixtures with lower binder contents without loss of performance. That is because in concretes with optimized granular skeletons, the reduction of cement content is a consequence of paste volume reduction, which outweighs any decrease in mechanical performance [31]. In this study, lower deviations did not result in lower void content, as shown in Figures 9 and 10. Instead, the distribution modulus had more influence on void content since it is directly related to the proportions of sand and gravel in the mixture.

[32] studied granular skeletons of binary, ternary, and quaternary mixtures with different aggregates, as well as the optimum q values for their aggregates that fit the modified A\&A model. It was found that the void index was influenced by the difference between the largest and the smallest particle sizes, that is, the lowest void contents occurred in compositions with the largest difference in size between particles of coarse and fine aggregates, and the highest void contents occurred in compositions with the smallest difference between particles of coarse and fine aggregates. This supports the general concept that for a mixture with minimum void content, its constituents should be particle sets with complementary aggregate size distributions. In this work, the aggregates PSD curves showed complementary distributions, which favored the aggregates compaction.

[32-34] focused on the study of particle packing in concretes, in which the optimization of the granular skeleton was carried out in an inverse way to that presented in this work: adjustments of the aggregate percentages were made first, and then the corresponding "q" value was determined. Even so, several "q" values were used in their studies: 0.29 in [34] study; $0.126-0.253$, with 9 values in total in [32] study; and 0.16 , 0.23 and 0.27 in [33] work. However, not all values produced mixtures with satisfactory performance. In [32] work, distribution modulus values from 0.201 to 0.253 generated appropriate self-compacting mixtures, but values from 0.126 to 0.194 produced non-cohesive mixtures with segregation. In [33], 0.16, 0.23 and 0.27 were the optimum values to produce concrete mixtures with compressive strengths of $80 \mathrm{MPa}, 40 \mathrm{MPa}$ and $25 \mathrm{MPa}$, respectively. In [34], 0.29 was the optimum value to produce their high-performance concrete mixture. These values of $\mathrm{q}$ are not far from those observed in the present study, that showed lower void index for q value around 0.3 .

Considering the aforementioned " $q$ " values, there is a diversity in the considered optimum value for the distribution modulus. This can be explained by the fact that it directly influences the concrete properties in the fresh (such as flowability and cohesion) and hardened (such as compressive strength and durability) state, and thus, the best value will also depend on the desired characteristics of the concrete.

\subsection{Concrete}

The application of linear programming for the aggregate packing produces the best fit to the ideal curve (CPFT of the mathematical model), showing the points where there is absence or excess of particles, which increase the calculated RSS (5). For concretes of superior packing (SQ25 and SQ35), a better fit is found, with only a deficiency of particles below $0.3 \mathrm{~mm}$ (Figure 13). As for concretes with intermediate packaging (IQ25 and IQ35), the lack of medium sand can be noticed when observing a greater dispersion in the diameters between 0.3 and $2.4 \mathrm{~mm}$ (Figure 14). [33, 34] present similar analysis and added particles to improve the fit of the curve. In this work, it was decided to work with different levels of packing and to assess whether this difference implies significant impacts on the compressive strength of the concretes. 


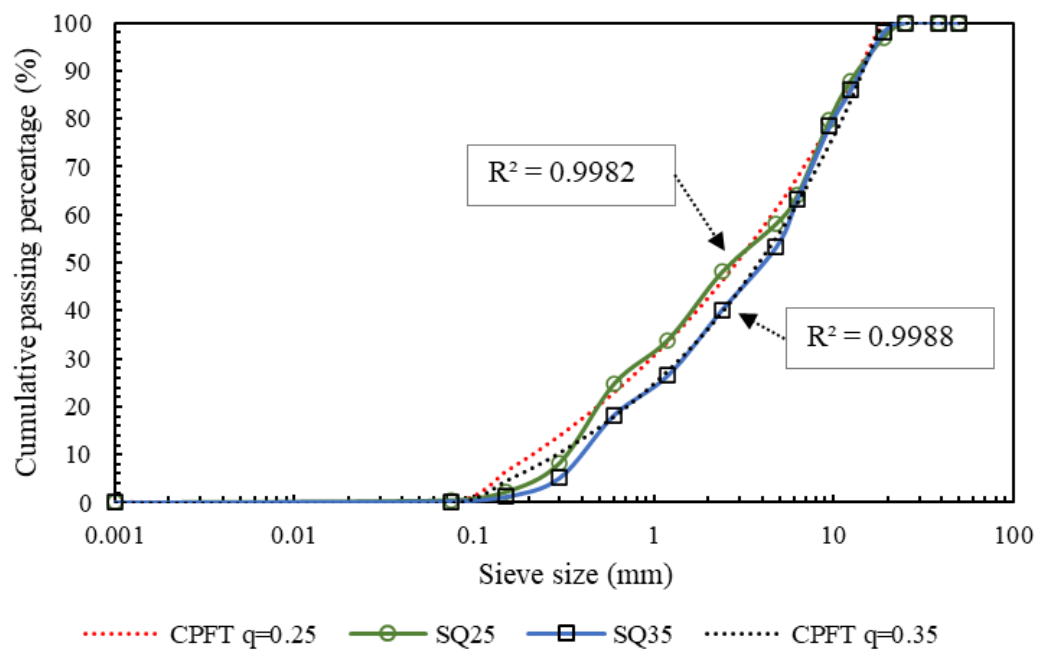

Figure 13: CPFT versus particle size distribution for concrete mixtures with superior packing (SQ25 and SQ35)

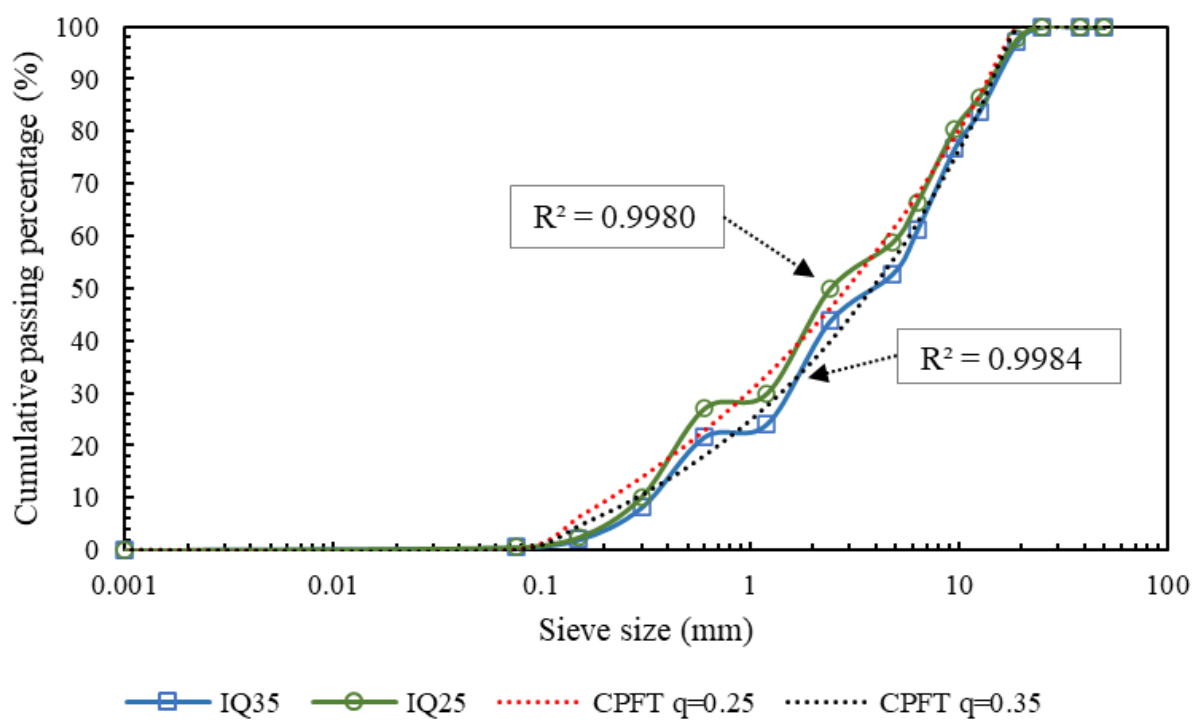

Figure 14: CPFT versus particle size distribution for concrete mixtures with intermediate packing (IQ25and IQ35)

Regarding concrete workability, GCBW concretes showed lower slump values, which was expected due to the higher volume of fine materials of these mixtures as well as the higher packing level reached. This was also observed in the studies [37-39]. Furthermore, there are also differences between concretes with a distribution modulus $q=0.25$ and $q=0.35$ and between concretes with superior $(\mathrm{S})$ and intermediate $(\mathrm{I})$ packing levels. The first case can be explained by the greater amount of fine sand in concretes with $q=0.25$, as seen in Table 4, section 2.2. The second case can be explained by the additional presence of the medium sand in $\mathrm{S}$ mixtures, which increases the packing level and makes harder the grain displacements. 


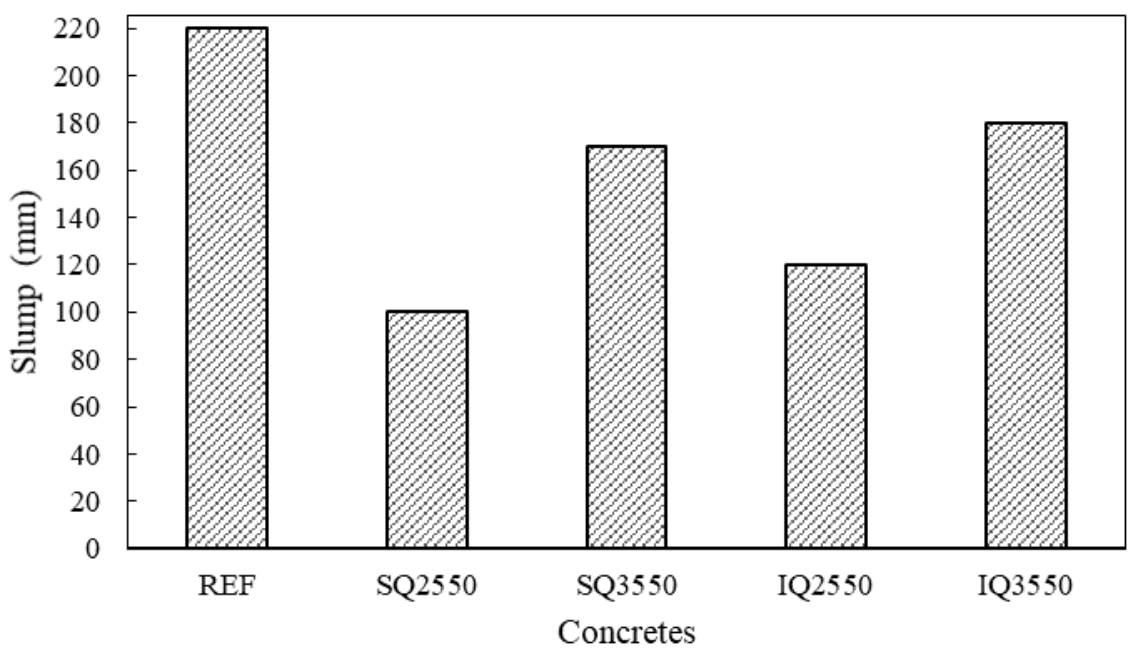

Figure 15: Slump test for concrete mixtures.

Taking into account the mechanical behavior of concretes, Figure 16 shows the results of compressive strength of the studied concretes, where can be observed a greater increase at 91 days in concretes with GCBW. This behavior can be explained by the pozzolanic activity (on a smaller scale) of this material that could be identified in previous studies [37, 40,41]. The pozzolanic properties were not extensively investigated in the GCBW used. Considering the variability of the firing temperature of the brick kilns, the composition of the ceramic mass and the fineness presented by the GCBW, this work focused on its filler properties.

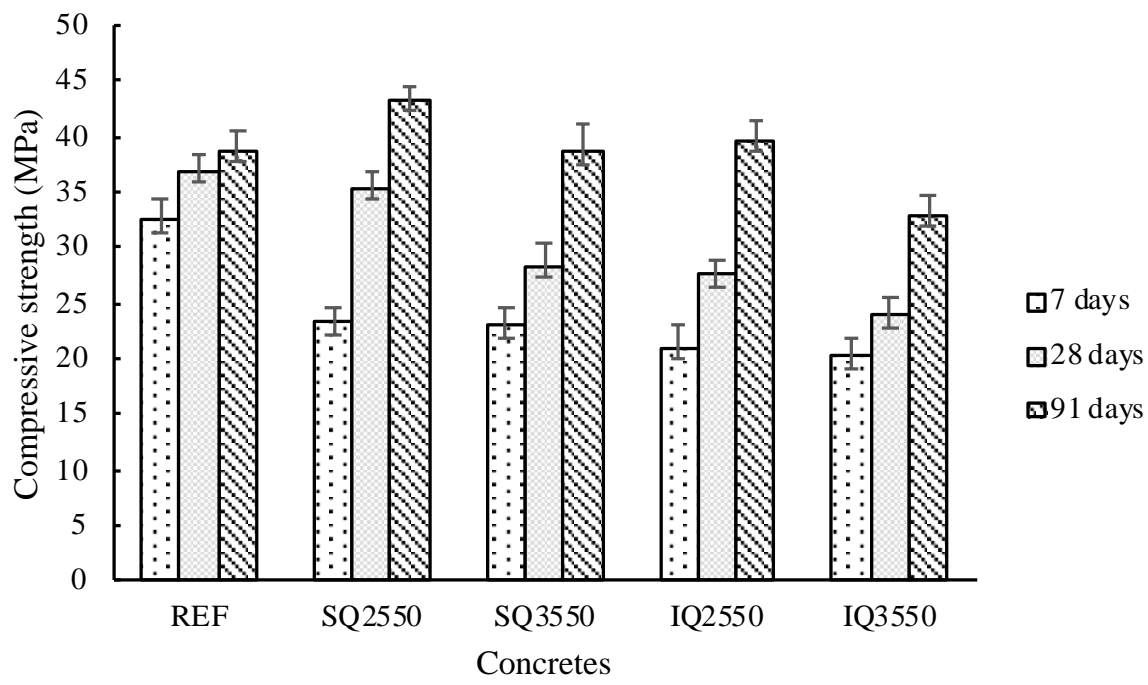

Figure 16: Compressive strength of studied concretes at 7, 27 and 91 days.

An important indicator when assessing the eco-efficiency of concretes is the binder intensity (bi) [3], which shows the amount of cement per cubic meter of concrete necessary to obtain 1 (one) MPa. Figure 17 shows the results of the particle packing efficiency thorough the bi with 28 days and the influence of GCBW activity thorough the $b i$ at 91 days. 
The results show the best performance of mixtures of superior packing and q value of 0.25 , a distribution modulus with less deviation (Figure 10) in relation to experimental and analytical mixtures. The results of [33] also show better performance in concretes with distribution coefficients less than 0.35 , increasing the mechanical performance as the value of q decreases.

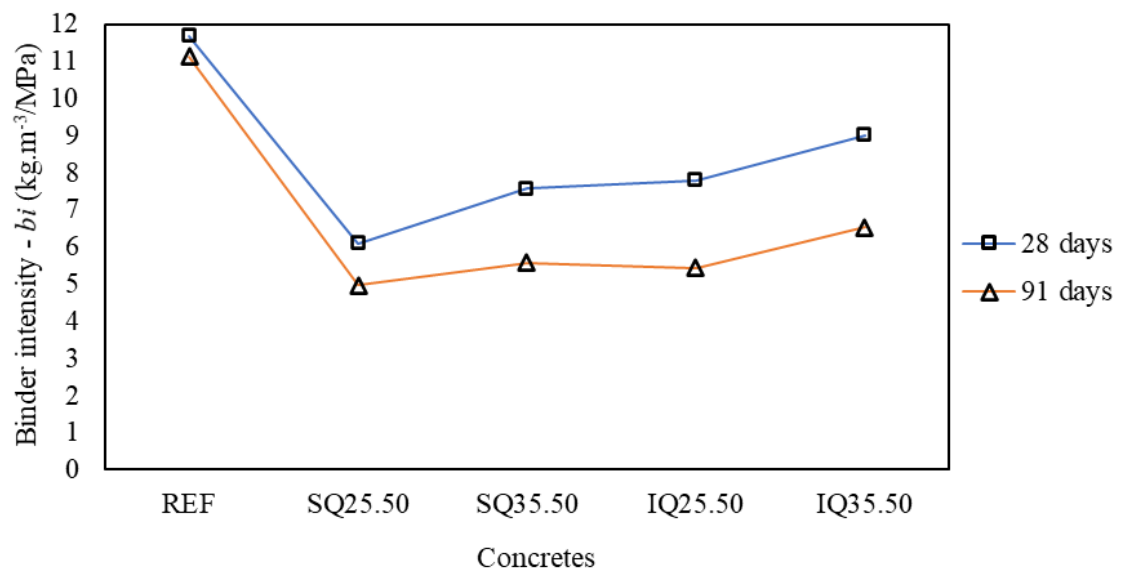

Figure 17: Binder intensity at 28 and 91 days for concrete mixtures.

Comparing the $b i$ values of the studied concretes with other works (Figure 18), it can be noticed that the SQ25.50 concrete $($ bi 28 days $=6.09$ ) has a good index for concretes with medium compressive strength (between 30 and $40 \mathrm{MPa}$ ), which tends to a better performance if considering bi at 91 days (Figure 17). Sequentially, concretes SQ3550, IQ2550, IQ 3550 and REF presented progressively worse bi results. Considering that Figure 18 shows the relationship between $b i$ and compressive strength of the twenty-one works mentioned in Table 1, it can be noticed the need to apply strategies to reduce the consumption of binder in concrete with lower resistance classes (below $50 \mathrm{MPa}$ ), since a large amount of the concretes with bi around 5 $\mathrm{kg} . \mathrm{m}^{-3} / \mathrm{MPa}$ have strengths greater than $50 \mathrm{MPa}$. As a result, the eco-efficient concrete design strategies need to be more widespread in the practices of day-to-day constructions.

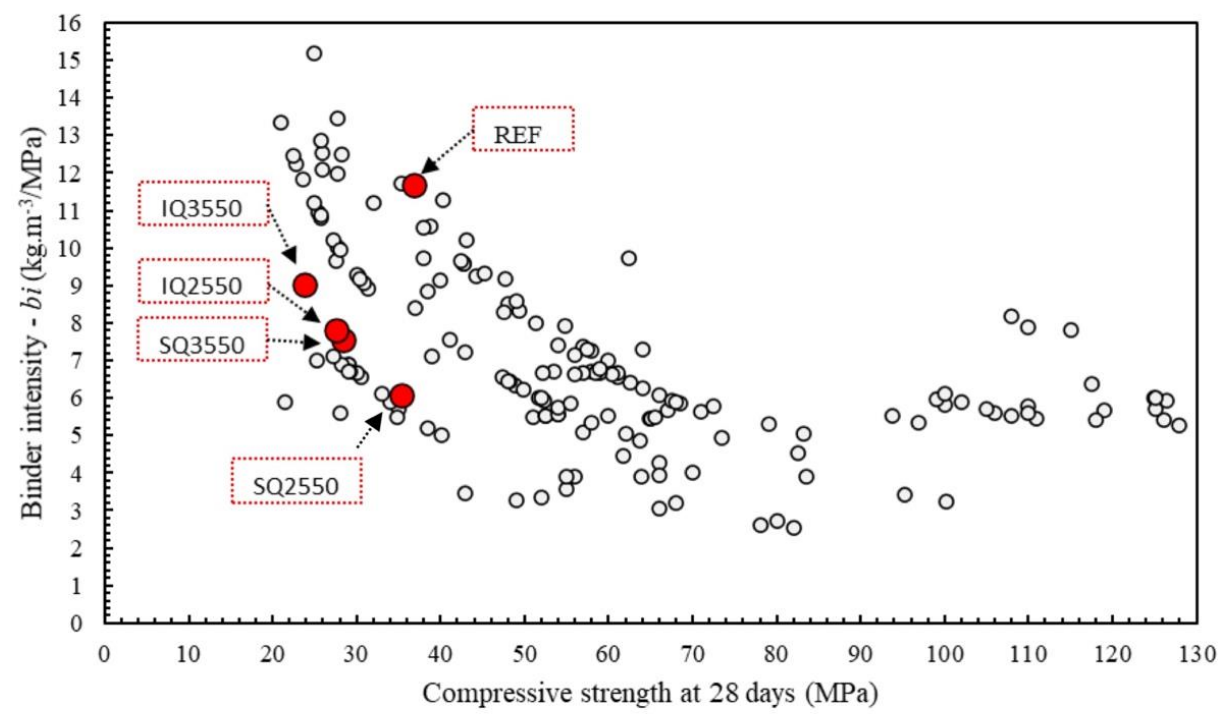

Figure 18: Relationship between binder intensity and compressive strength at 28-days - literature and experimental data. 


\section{CONCLUSION}

This study aimed to reduce the void content of aggregate skeletons as a solution to increase cement efficiency in low-binder concretes. A practical numerical simulation method using the modified Andreasen \& Andersen packing model was applied to find the optimum percentages of each aggregate which minimizes the deviations between the numerical and mathematical PSD curves. Considering the limits of this work, the main conclusions that can be drown are:

- The mixtures with the lowest deviations did not have the lowest void content. In this case, the distribution modulus was a more prevalent factor;

- Regarding the deviations between the numerical and mathematical PSD curves, for a given set of sand and gravel aggregates, there is a distribution modulus value below which sand is the top deviation contributor and above which gravel is the top deviation contributor. In the present case, this value was 0.60 for aggregate batch 1 and 0.47 for aggregate batch 2;

- There is an inherent error when using the modified A\&A model, which considers particles to be of spherical shape, to compose concrete aggregate mixtures with optimized packing. This is due to the real aggregate particles not being spheres. However, this was not enough to affect the accuracy of the packing optimization used in this study;

- There is a limit to the distribution modulus after which the void content of aggregate skeletons tends to increase. In this study, that was 0.30 . However, depending on the aggregate morphology, this value may vary.

- Concretes with superior packing ( $\mathrm{S}$ concrete) and with the lowest distribution factor $(\mathrm{q}=0.25)$ showed better performance than concretes with intermediate packing (I concrete) and reference concrete. A binder intensity around 6 was reached at 28 days and below 5 at 91 days for SQ2550 concrete.

\section{BIBLIOGRAPHY}

[1] BENHELAL, E., ZAHEDI, G., SHAMSAEI, E., et al. "Global strategies and potentials to curb $\mathrm{CO}_{2}$ emissions in cement industry," Journal of Cleaner Production, v. 51, pp. 142-61, 2013.

[2] ANDREW, R.M., "Global $\mathrm{CO}_{2}$ emissions from cement production", Earth System Science Data, v. 10, n. 1, pp. 195-217, 2018.

[3] DAMINELI, B.L., KEMEID, F.M., AGUIAR, P.S., et al. "Measuring the eco-efficiency of cement use," Cement and Concrete Composites, v. 32, n. 8, pp. 555-62, 2010.

[4] KAVITHA, O.R., SHANTHI, V.M., ARULRAJ, G.P., et al. "Microstructural studies on eco-friendly and durable Self-compacting concrete blended with metakaolin", Applied Clay Science, v. 124-125, pp. 143-9, May. 2016.

[5] DAMINELI, B.L., PILEGGI, R.G., JOHN, V.M., "Influence of packing and dispersion of particles on the cement content of concretes", Revista IBRACON de Estruturas e Materiais, v. 10, n. 5, pp. 998-1024, 2017.

[6] RODRIGUES, C.R. S., FUCALE, S., "Dosagem de concretos produzidos com agregado miúdo reciclado de resíduo da construção civil", Ambiente Construído, v. 14, n. 1, pp. 99-111, 2014.

[7] WANG, X., YU, R., SHUI, Z., et al. "Mix design and characteristics evaluation of an eco-friendly UltraHigh Performance Concrete incorporating recycled coral based materials", Journal of Cleaner Production, v. 165, pp. 70-80, 2017.

[8] YOUSUF, S., SANCHEZ, L.F.M., SHAMMEH, S.A., "The use of particle packing models (PPMs) to design structural low cement concrete as an alternative for construction industry", Journal of Building Engineering, v. 25, pp. 100815, May. 2019.

[9] PRADHAN, S., KUMAR, S., BARAI, S.V., "Recycled aggregate concrete: Particle Packing Method (PPM) of mix design approach", Construction and Building Materials, v. 152, pp. 269-84, 2017.

[10] FURNAS, C. C., "Grading Aggregates - I. - Mathematical Relations for Beds of Broken Solids of Maximum Density", Industrial \& Engineering Chemistry, v. 23, n. 9, pp. 1052-8, 1931.

[11] WESTMAN, A.E.R., HUGILL, H.R., "The packing of particles", Journal of the American Ceramic Society, v. 13, n. 10, pp. 767-79, 1930.

[12] FUNK, J.E., DINGER, D.R., Predictive Process Control of Crowded Particulate Suspensions, Applied to Ceramic Manufacturing, Boston, Kluwer Academic Publishers, 1994.

[13] FULLER, W.B., THOMPSON, S.E., "The Laws of Proportioning Concrete", Transactions of the 
American Society of Civil Engineers, v. LIX, n. 2, pp. 67-143, 1907.

[14] ANDREASEN, A.H.M., ANDERSEN, J., "Ueber die Beziehung zwischen Kornabstufung und Zwischenraum in Produkten aus losen Körnern (mit einigen Experimenten)", Kolloid-Zeitschrift, v. 50, n. 3 , pp. 217-28, 1930.

[15] MEHDIPOUR, I., KHAYAT, K.H., "Effect of particle-size distribution and specific surface area of different binder systems on packing density and flow characteristics of cement paste", Cement and Concrete Composites, v. 78, pp. 120-31, 2017.

[16] TUTIKIAN, B.F., DAL MOLIN, D.C., Concreto auto-adensável, 1 ed., São Paulo, Pini, 2008.

[17] ABD ELRAHMAN, M., HILLEMEIER, B., "Combined effect of fine fly ash and packing density on the properties of high performance concrete: An experimental approach", Construction and Building Materials, v. 58, pp. 225-33, 2014.

[18] FRANCO DE CARVALHO, J.M., MELO, T.V., FONTES, W.C., et al. "More eco-efficient concrete: An approach on optimization in the production and use of waste-based supplementary cementing materials", Construction and Building Materials, v. 206, pp. 397-409, 2019.

[19] SUNAYANA, S., BARAI, S.V., "Recycled aggregate concrete incorporating fly ash: Comparative study on particle packing and conventional method", Construction and Building Materials, v. 156, pp. 376-86, 2017.

[20] ASHISH, D.K., VERMA, S.K., "Determination of optimum mixture design method for self-compacting concrete: Validation of method with experimental results", Construction and Building Materials, v. 217, pp. 664-78, 2019.

[21] KANADASAN, J., RAZAK, H.A., "Mix design for self-compacting palm oil clinker concrete based on particle packing”, Materials \& Design (1980-2015), v. 56, pp. 9-19, 2014.

[22] SU, N., HSU, K.C., CHAI, H.W., "A simple mix design method for self-compacting concrete”, Cement and Concrete Research, v. 31, n. 12, pp. 1799-807, 2001.

[23] SU, N., MIAO, B., "A new method for the mix design of medium strength flowing concrete with low cement content", Cement and Concrete Composites, v. 25, n. 2, pp. 215-22, 2003.

[24] BARBOZA, L.S., ALMEIDA FILHO, F.M., "Concreto autoadensável com baixo consumo de cimento: impacto da redução do consumo de cimento na resistência à compressão", Revista Matéria, v. 23, n. 3, 2018.

[25] HÜSKEN, G., BROUWERS, H.J.H, "A new mix design concept for earth-moist concrete: A theoretical and experimental study", Cement and Concrete Research, v. 38, n. 10, pp. 1246-59, 2008.

[26] YU, R., VAN ONNA, D.V., SPIESZ, P., et al. BROUWERS, H.J.H., "Development of UltraLightweight Fibre Reinforced Concrete applying expanded waste glass", Journal of Cleaner Production, v. 112, pp. 690-701, 2016.

[27] YU, R., SPIESZ, P., BROUWERS, H.J.H., "Development of an eco-friendly Ultra-High Performance Concrete (UHPC) with efficient cement and mineral admixtures uses", Cement and Concrete Composites, v. 55, pp. 383-94, 2015.

[28] SUN, Y., WANG, Z., GAO, Q., CHENGUANG, L., "A new mixture design methodology based on the Packing Density Theory for high performance concrete in bridge engineering", Construction and Building Materials, v. 182, pp. 80-93, 2018.

[29] MOINI, M., FLORES-VIVIAN, I., AMIRJANOV, A., et al. "The optimization of aggregate blends for sustainable low cement concrete", Construction and Building Materials, v. 93, pp. 627-34, 2015.

[30] OLIVEIRA, C.O.E., MACIEL, G.F., CASTRO, A.L., et al., "Impacto do conceito de empacotamento de partículas na dosagem de concretos de alto desempenho", Revista Matéria, v. 23, n. 1, 2018.

[31] LOPES, H.M.T., PEÇANHA, A.C.C., CASTRO, A.L., "Considerações sobre a eficiência de misturas de concreto de cimento Portland com base no conceito de empacotamento de partículas", Revista Matéria, v. 25, n. $1,2020$.

[32] ASSOCIAÇÃO BRASILEIRA DE NORMAS TÉCNICAS. NBR NM 24: 2003: Agregados Determinação da composição granulométrica. Rio de Janeiro, p. 6, 2003.

[33] ASSOCIAÇÃO BRASILEIRA DE NORMAS TÉCNICAS. NBR NM 45: 2006: Agregados Determinação da massa unitária e do volume de vazios. Rio de Janeiro, p. 18, 2006.

[34] MELO, C.V.A., GOMES, P.C.C., MORAES, K.A.M., "A study of packing parameters that influence the fresh properties of self-compacting concrete", Cerâmica, v. 65, n. 375, pp. 432-42, 2019. 
[35] GRAZIA, M.T., SANCHEZ, L.F.M., ROMANO, C.O., et al. "Investigation of the use of continuous particle packing models (PPMs) on the fresh and hardened properties of low-cement concrete (LCC) systems", Construction and Building Materials, v. 195, p. 524-36, 2019.

[36] BESERRA, A.V.S., DIAS, L.D.S., SANTOS, R.A.., "Análise do comportamento de concreto com adição de cinza de biomassa vegetal submetido ao ataque de íons sulfato", Revista Matéria, v. 25, n. 4, 2020.

[37] PACHECO-TORGAL, F., JALALI, S., "Compressive strength and durability properties of ceramic wastes based concrete", Materials and Structures, v. 44, p. 155-67, 2011.

[38] SALES, A.T.C., FILHO, R.S.A., "Efeito do pó de resíduo cerâmico como adição ativa para o concreto", Ambiente Construído, v. 14, n. 1, p. 113-125, 2014.

[39] MEIRA, G.R., FERREIRA, P.R.R., JERÔNIMO, V.L., et al. "Comportamento de concreto armado com adição de resíduos de tijolo cerâmico moído frente à corrosão por cloretos”, Ambiente Construído, v. 14, n 4, p. 33-52, 2014.

[40] JERÔNIMO, V.L., MEIRA, G.R., DA SILVA FILHO, L.C.P., "Performance of self-compacting concretes with wastes from heavy ceramic industry against corrosion by chlorides", Construction and Building Materials, v. 169, p. 900-10, 2018.

[41] ARAÚJO, R. A., MENEZES, A.L.R., CABRAL, K.C., et al. "Evaluation of the pozzolanic activity of red ceramic waste using mechanical and physicochemical methods", Cerâmica, v. 65, p. 461-9, 2019.

\section{ORCID}

Robson Arruda dos Santos

Gibson Rocha Meira

Wesley Vítor Dantas de Carvalho Bezerra

Francisco Alisson Vieira Braga

Dayvison Leoncio de Pontes https://orcid.org/0000-0001-5615-4365

https://orcid.org/0000-0002-2010-5315

https://orcid.org/0000-0003-4225-5880

https://orcid.org/0000-0002-0744-3547

https://orcid.org/0000-0002-9510-4886 